\title{
Lethal and sublethal effects of pesticides used in Brazilian citrus groves on Panonychus citri (Acari: Tetranychidae)
}

\author{
Efeitos letais e subletais de agrotóxicos utilizados em citros sobre o ácaro \\ Panonychus citri (Acari: Tetranychidae)
}

\author{
Everaldo Batista Alves ${ }^{1 *}$, Nádia Fernanda Bertan Casarin², Celso Omoto²

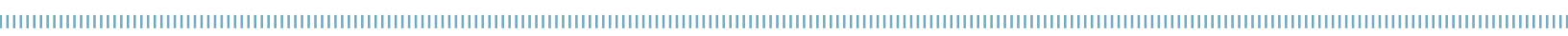

\begin{abstract}
Pesticides have been blamed as the principal factor responsible for biological disequilibrium favoring the population increase of Panonychus citri (McGregor) in Brazilian citrus groves. In order to generate subsidies for the integrated management of this pest, we evaluated the lethal and sublethal effects of pesticides used in citrus on $P$. citri. We tested 18 pesticides by evaluating mortality of adult female, egg viability and adult avoidance. For imidacloprid, pyriproxyfen, dimethoate, deltamethrin, lambda-cyhalothrin and lime sulfur, the principal insecticides used in Brazilian orchards, the oviposition behavior and the incidence of adult females on discontinuous pesticide residues were evaluated. The pesticides which caused adult $P$. citr $i$ mortality were: abamectin (94\%), dimethoate (86\%), lime sulfur (69\%), fenpropathrin (44\%), diafenthiuron (25\%) and lambda-cyhalothrin $(23 \%)$. The pesticides affecting egg viability were: fenpropathrin $(53 \%)$, dimethoate $(30 \%)$ and lime sulfur (22\%). Fenpropathrin, lambda-cyhalothrin and lime sulfur caused repellent effects of 55, 45 and $22 \%$, respectively. P. citri preferred areas untreated with deltamethrin, lambda-cyhalothrin and lime sulfur for oviposition and permanence, but the species could not distinguish areas treated with imidacloprid, pyriproxyfen and dimethoate. The insecticides abamectin, dimethoate and diafenthiuron affected survival and did not cause changes in $P$. citri behavior. These pesticides should be used mainly in periods $P$. citri occurs. On the other hand, fenpropathrin, lambda-cyhalothrin, lime sulfur and deltamethrin affect dispersal behavior, oviposition and $P$. citri incidence and their use should be avoided.
\end{abstract}

KEYWORDS: integrated pest management; citrus red mite; oviposition; repellency; pesticides.
RESUMO: O intenso uso de pesticidas na citricultura tem sido apontado como o principal fator responsável por desequilíbrios biológicos, favorecendo o aumento populacional de Panonychus citri (McGregor) na citricultura brasileira. Para gerar subsídios ao manejo integrado dessa praga, avaliaram-se os efeitos letais e subletais de agrotóxicos utilizados em citros sobre $P$. citri. Avaliaram-se 18 agrotóxicos na mortalidade de fêmeas adultas, viabilidade de ovos e repelência de $P$. citri. Foram também avaliados o comportamento de oviposição e a incidência de $P$. citri em superfícies com áreas tratadas e não tratadas com imidacloprid, piriproxifem, dimetoato, deltametrina, lambda-cialotrina e calda sulfocálcica, por serem os principais inseticidas utilizados nos pomares brasileiros. Os pesticidas que causaram mortalidade em adultos de $P$. citri foram abamectina (94\%), dimetoato (86\%), calda sulfocálcica (69\%), fempropatrina (44\%), diafentiurom (25\%) e lambda-cialotrina (23\%). Os pesticidas que afetaram a viabilidade de ovos foram fempropatrina (53\%), dimetoato (30\%) e calda sulfocálcica (22\%). Quanto aos efeitos subletais, fempropatrina, lambda-cialotrina e calda sulfocálcica ocasionaram repelências de 55, 45 e 22\%, respectivamente. P. citri preferiu áreas não tratadas com deltametrina, lambda-cialotrina e calda sulfocálcica para oviposição e permanência. Em contraste, $P$. citri não foi capaz de distinguir superfícies tratadas com imidacloprid, piriproxifem e dimetoato. Os inseticidas abamectina, dimetoato e diafentiurom afetaram a sobrevivência e não causaram mudanças no comportamento de $P$. citri, podendo ser utilizados principalmente em períodos que P. citri ocorre. Em contrapartida, fempropatrina, lambda-cialotrina, calda sulfocálcica e deltametrina afetaram o comportamento de dispersão e oviposição de $P$. citri e deveriam ser evitados.

PALAVRAS-CHAVE: manejo integrado de pragas; ácaro purpúreo dos citros; oviposição; repelência; agrotóxico.

'PROMIP Consultoria e Assessoria em Agronomia Ltda. - Conchal (SP), Brazil

'Escola Superior de Agricultura "Luiz de Queiroz", Universidade de São Paulo - Piracicaba (SP), Brazil

*Corresponding author: everaldo@promip.agr.br

Received on: 08/20/2016. Accepted on: 04/05/2018

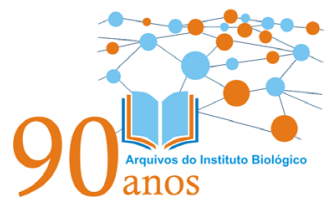




\section{INTRODUCTION}

The use of pesticides in Brazilian citrus has increased dramatically over the last few years due to the appearance of new pests and diseases. Among these pests, there is the citrus psyllid Diaphorina citri (Kumayama), the vector of Huanglongbing, which has increased insecticide use by more than $40 \%$ in this crop (COSTA et al., 2010; QURESHI et al., 2014). Monthly insecticide applications are now made in São Paulo state, Brazil, the main citrus producing region, responsible for $80 \%$ of Brazilian production, to halt the advance of the disease (YAMAMOTO et al., 2009). There has also been an increase in fungicide use during this period due to the dissemination of postbloom fruit drop disease (Colletotrichum acutatum Simmonds) and citrus black spot (Guignardia citricarpa Kiely) (ROBERTO; BORGES, 2009; ROSSETTO et al., 2011).

Intensive pesticide use in Brazilian citrus has caused biological disequilibrium, resulting in secondary pests becoming important, pest resurgence and the development of pesticide resistance (SATO, 2005; OMOTO et al., 2008; BOBOT et al., 2011). Important secondary pests include the defoliating mites Panonychus citri (McGregor) and Tetranychus mexicanus (McGregor), and descriptions of their damage and spraying control measures have been recorded in isolated instances, principally in drought years (ZANARDI, 2015; ZANARDI et al., 2015).

In the United States, Turkey, China and Japan, P. citri is considered the key citrus pest (KASAP, 2009; HU et al., 2010; FADOMIRO et al., 2013). In Brazil, at least one acaricide application per year is for controlling defoliating mites in most citrus regions. P. citri is mainly present in the South and Southeast regions of Sáo Paulo state, where temperatures are lower, whereas T. mexicanus is observed in the Central and Northern regions of the state, where temperatures are high (YAMAMOTO; ZANARDI, 2013).

The reduced number of acaricides with a distinct mode of action registered for Brazilian citrus and destined principally for managing Brevipalpus yothersi Baker, one of the main pest mites of Brazilian citrus, means that the use of these products to control a new pest, such as defoliating mites, must be carefully analyzed (AGROFIT (http://extranet.agricultura. gov.br/agrofit_cons/principal_agrofit_cons); BEARD et al., 2015; MINEIRO et al., 2015). Control strategies for defoliating mites should be implemented aiming the preservation of existing acaricide products used in managing $B$. yothersi resistance (OMOTO et al., 2008). Thus, the effects of insecticides and fungicides used in citrus should be evaluated for defoliating mites in order to know their lethal and sublethal effects and to collect data for positioning these products according to the occurrence of pest population (NOHARA et al., 2000; GRAFTON-CARDWELL et al., 2008).

The objective of the present study was to evaluate the lethal and sublethal effects on $P$. citri of the main pesticides used in citrus to position these products in different pest infestation periods.

\section{MATERIAL AND METHODS}

\section{Rearing of Panonychus citri}

Laboratory colony of $P$. citri were established by individuals collected from a non-commercial citrus groves without spraying of pesticides of the University of São Paulo (USP), in Piracicaba, São Paulo state, Brazil. The mites were reared on the leaves of Pera or Valencia varieties, resting on a foam mat and wrapped in moist cotton wool. Every 15 days, the rearing arenas were replaced with new leaves and the new arenas were infested with pieces of leaves with citrus red mite nymphs and adults. Rearing was done in a climatized room at $25 \pm 2^{\circ} \mathrm{C}$, $70 \pm 10 \%$ RH (Relative Humidity) and a $14 \mathrm{~h}$ photophase.

\section{Pesticides}

Eighteen pesticides recommended for pest and disease control in the integrated production of citrus were evaluated. The highest recommended dose for pest control in citrus was chosen to be tested on P. citri (Table 1).

\section{Effect of pesticides on egg viability, mortality and adult avoidance}

A direct contact and residual bioassay method by spraying, using a Potter Tower (Burkard Manufacturing, Rickmansworth, Hertfordshire, United Kingdom), calibrated at $10 \mathrm{psi}(68.95 \mathrm{kPa})$, was used to expose 24-hour-old eggs and 3- to 7 day-old adult females of $P$. citri to the pesticides. A volume of $2 \mathrm{~mL}$ of solution was used for each spraying, resulting in the average deposition of moist residue of $1.60 \mathrm{mg} / \mathrm{cm}^{2}$.

Arenas with $3.1 \mathrm{~cm}$ diameter made with Pera orange leaves, kept on a foam mat and wrapped in moistened cotton wool, were used as the substrate for spraying and maintaining the eggs and mites. About 10 female $P$. citri adults were infested on the adaxial surface of each arena. For the trials with eggs, the females were removed from the arenas 24 hours after infestation, and the eggs were counted and then sprayed.

For each product, the bioassays were replicated two or three times over time. In each replicate, it was utilized four arenas. After spraying, the arenas were kept in climatized chambers at $25 \pm 1^{\circ} \mathrm{C}, 70 \pm 10 \% \mathrm{RH}$ and a $14 \mathrm{~h}$ photophase. Mortality and adult avoidance were evaluated on the third day, whereas evaluations for egg viability were done 11 days after spraying. Avoidance was determined by considering those mites lost on the cotton wool barrier. Bioassays in which the control with 
water showed mite mortality or loss on the barrier higher than $10 \%$ were discarded.

The percentage data for mortality, egg viability and avoidance were subjected to ANOVA assumptions for normality and homoscedasticity that did not indicate the need for data transformation. Then, data were submitted to analysis of variance (PROC GLM; Statistical Analysis System - SAS) (SAS INSTITUTE, 2002). Treatment means were separated by Tukey's test at $\mathrm{a}=0.05$.

\section{Panonychus citri behavior on discontinuous pesticide residues}

The behavior of $P$. citri was evaluated for imidacloprid, pyriproxyfen, dimethoate, deltamethrin, lambda-cyhalothrin and lime sulfur. We used the highest dosage of the products recommended for citrus pests (Table 1). The lime sulfur is one of the few product choices in organic agriculture to control insects and mites, and therefore was chosen for this study, while other products were chosen because they are representative of different chemical groups used intensively in control of $D$. citri. The results of efficiency and avoidance of the products in $P$. citri were also used for selection of these insecticides.

Oviposition behavior and the incidence of adult females were evaluated on the adaxial surface of the Pera orange leaf having discontinuous residues of insecticides. Square frames positioned on the orange leaf surface allowed the presence of treated and untreated areas of $1 \mathrm{~cm}^{2}$ each on the same surface (KOLMES et al., 1991). The treated and untreated areas were arranged in array-type "chess board" on a leaf area of $4 \times 2 \mathrm{~cm}$, delimited by moistened cotton wool to prevent mite escape (KOLMES et al., 1991; BOWIE et al., 2001). Spraying was done with the help of a Potter tower.

The treatments evaluated had 10 repetitions, with each repetition composed of an arena infested with 10 mites and kept in a climatized chamber at $25 \pm 1^{\circ} \mathrm{C}, 70 \pm 10 \% \mathrm{RH}$ and a photophase of $14 \mathrm{~h}$. Mite incidence was evaluated $24 \mathrm{~h}$ after infestation, whereas oviposition preference was observed $48 \mathrm{~h}$ after female infestation.

A binomial frequency test $(\mathrm{p} \leq 0.05)$ was used to determine oviposition preference and mite incidence between treated and untreated surfaces, when differences from a 50:50 ratio were investigated (PROC NPAR1WAY) (TEODORO et al., 2009; SAS INSTITUTE, 2002).

\section{RESULTS}

\section{Pesticide effects on egg viability, mortality and adult avoidance}

The pesticides abamectin, dimethoate, lime sulfur, fenpropathrin, diafenthiuron and lambda-cyhalothrin showed a

Table 1. Pesticides and their highest recommended rate for pest or disease control in Brazilian citrus.

\begin{tabular}{|c|c|c|c|}
\hline Chemical group/active ingredient & Action & Comercial product & g a.i./ $100 \mathrm{~L}$ of $\mathrm{H}_{2} \mathrm{O}$ \\
\hline Imidacloprid & $I^{*}$ & Provado $200 \mathrm{CS}$ & 10.00 \\
\hline Thiametoxam & 1 & Actara 250 WG & 5.00 \\
\hline Deltamethrin & 1 & Decis 25 CE & 0.75 \\
\hline Etofenprox & 1 & Trebon $100 \mathrm{CS}$ & 2.50 \\
\hline Lambda-cyhalothrin & 1 & Karate Zeon $50 \mathrm{CS}$ & 1.00 \\
\hline Fenpropathrin & $A / I$ & Meothrin 300 EC & 15.00 \\
\hline Dimethoate & $A / I$ & Perfekthion EC & 80.00 \\
\hline Abamectin & $A / I$ & Vertimec $18 \mathrm{EC}$ & 0.54 \\
\hline Diafenthiuron & $A / I$ & Polo 500 WP & 7.50 \\
\hline Lime sulfur & $A / I$ & Lime Sulfur & 600.00 \\
\hline Buprofezin & 1 & Applaud 250 & 50.00 \\
\hline Lufenuron & 1 & Match EC & 3.75 \\
\hline Pyriproxyfen & 1 & Tiger $100 \mathrm{EC}$ & 10.00 \\
\hline Mancozeb & $A / F$ & Dithane NT & 200.00 \\
\hline Copper oxychloride & $\mathrm{F}$ & Cobox & 210.00 \\
\hline Strobilurin & $\mathrm{F}$ & Comet EC & 3.75 \\
\hline Thiophanate methyl & $\mathrm{F}$ & Cercobin $500 \mathrm{sC}$ & 50.00 \\
\hline Triazol & $\mathrm{F}$ & Score EC & 5.00 \\
\hline
\end{tabular}

g a.i.: grams of active ingredient; I: insecticide; A/I: acaricide and insecticide; A/F: acaricide and fungicide; F: fungicide. 
significant lethal effect on adult mortality $(\mathrm{F}=51.60$, degrees of freedom - d.f. $=18 ; 49$, p <0.0001) (Fig. 1), with mortalities of $94,86,69,44,25$ and $23 \%$, respectively. However, only fenpropathrin, dimethoate and lime sulfur affected egg mortality significantly $(\mathrm{F}=17.28$; d.f. $=18 ; 46 ; \mathrm{p}<0.0001)$ (Fig. 2$)$, with reductions in viability of 53,30 and $22 \%$, respectively.
Most embryos developed with fenpropathrin, but the larvae did not emerge from the eggs, which make them be considered unviable, whereas there was no embryo development with dimethoate and lime sulfur.

With regard to the sublethal effects, evaluated by observing the mites lost on the cotton wool barrier, a high avoidance

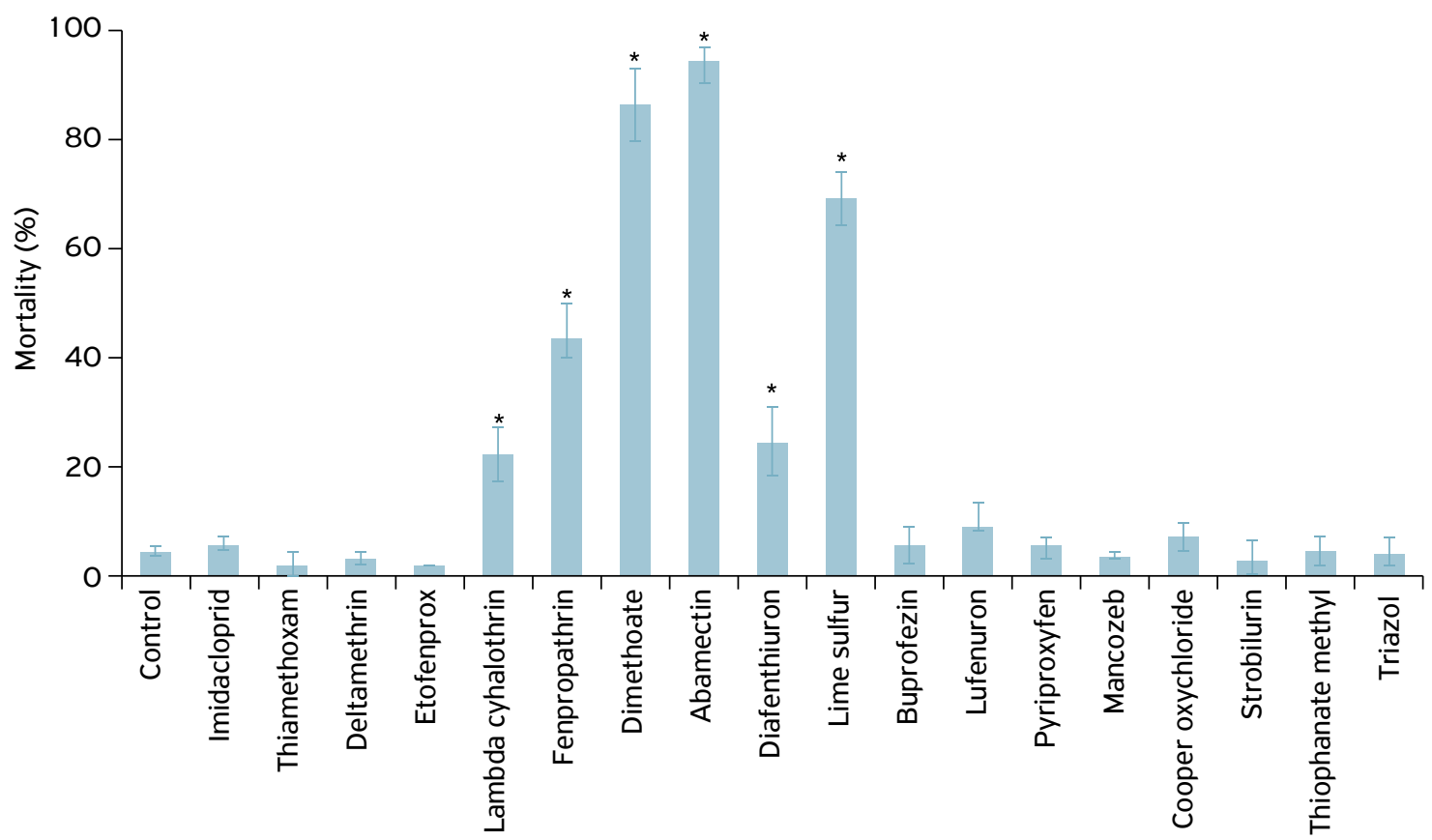

*Significant mortality.

Figure 1. Pesticide effect on the mortality (\%) of Panonychus citri adults, $72 \mathrm{~h}$ after exposure.

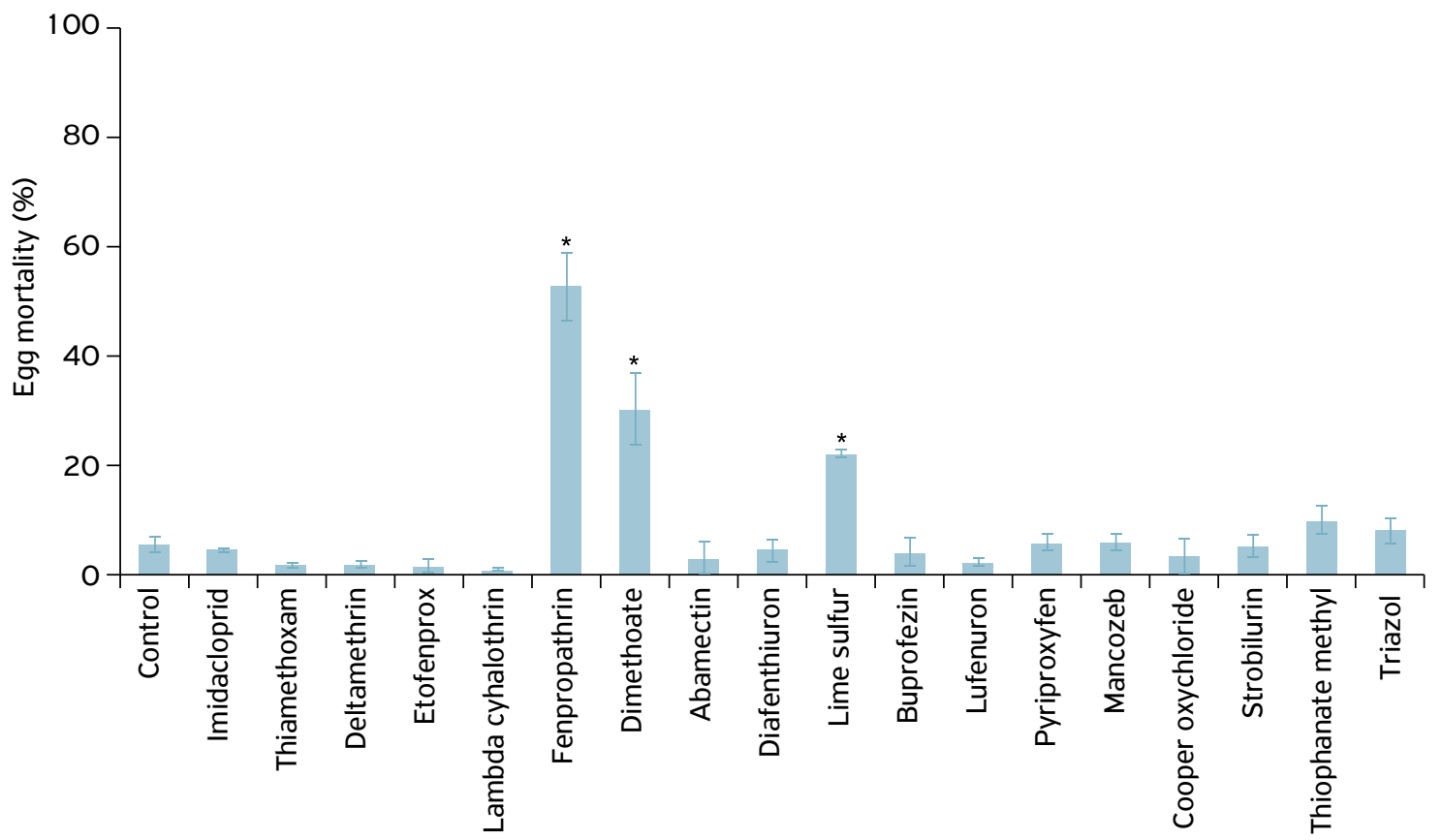

*Significant treatment effect on egg mortality.

Figure 2. Pesticide effect on the egg mortality (\%) of Panonychus citri. 
was seen for fenpropathrin (55\%), lambda-cyhalothrin (45\%) and lime sulfur $(22 \%)(\mathrm{F}=19.58$; d.f. $=18 ; 46 ; \mathrm{p}<0.001)$, whereas the remaining pesticides showed mite losses of less than $10 \%$ on the cotton wool barrier, not differing from the control (Fig. 3).

\section{Panonychus citri behavior on discontinuous pesticide residues}

Oviposition behavior on discontinuous residues of the "chess board" type had significant effect on oviposition preference for areas untreated with deltamethrin ( $\mathrm{p}=0.0489)$, lambda-cyhalothrin $(\mathrm{p}=0.003)$ and lime sulfur $(\mathrm{p}=0.0004)$, whereas the results for imidacloprid $(\mathrm{p}=0.5204)$, pyriproxyfen $(\mathrm{p}=0.7324)$, dimethoate $(\mathrm{p}=0.0847)$ and the control $(\mathrm{p}=0.7621)$ were not significant (Fig. 4). The incidence of females on untreated surfaces was significantly greater for deltamethrin $(\mathrm{p}=0.0199)$, lambda-cyhalothrin ( $\mathrm{p}=0.0018)$ and lime sulfur $(\mathrm{p}=0.0002)$, but not significant for imidacloprid $(\mathrm{p}=0.8193)$, pyriproxyfen $(\mathrm{p}=0.6904)$, dimethoate $(\mathrm{p}=0.8131)$ and the control $(\mathrm{p}=0.3939)$ (Fig. 5).

\section{DISCUSSION}

The effect on adult $P$. citri mortality of abamectin, dimethoate and fenpropathrin has also been described in the literature (SATO et al., 1992; HE et al., 2011). In the case of eggs, there are also descriptions of the insecticides acephate and fenpropathrin affecting egg viability (SATO et al., 1992). However, there are no studies evaluating effects on $P$. citri mortality and egg viability of the remaining pesticides tested in the present study.

On discontinuous pesticide residues, $P$. citri preferred areas free of the residues of the insecticides deltamethrin, lambda-cyhalothrin and lime sulfur, for feed and oviposition, whereas for imidacloprid, pyriproxyfen and dimethoate the mite could not distinguish between treated and untreated areas. In the case of dimethoate, Figure 4 shows a preference oviposition by untreated areas, while the statistical analysis determined this effect was not significant parameter. A review of mortality data showed that the residue discontinuous dimethoate caused $94 \%$ mortality in adults, while other products showed less than $10 \%$ of mortality. Consequently, the number of eggs laid in the dimethoate arenas was lower, which may explain the lack of significance of the data evaluated.

Studies evaluating the sublethal effects of the pyrethroid esfenvalerate on Panonychus ulmi (Koch) and Tetranychus urticae (Koch) also showed that these species preferred to stay in and oviposit on areas free of the product, as well as presenting reduction in oviposition compared to the control (BOWIE et al., 2001).

In integrated pest management, pesticide use should be based not only on product efficiency, but also on the effects products cause to non-target pests and beneficial organisms. Therefore, the evaluation of lethal and sublethal effects of these products on non-target pests is essential for positioning

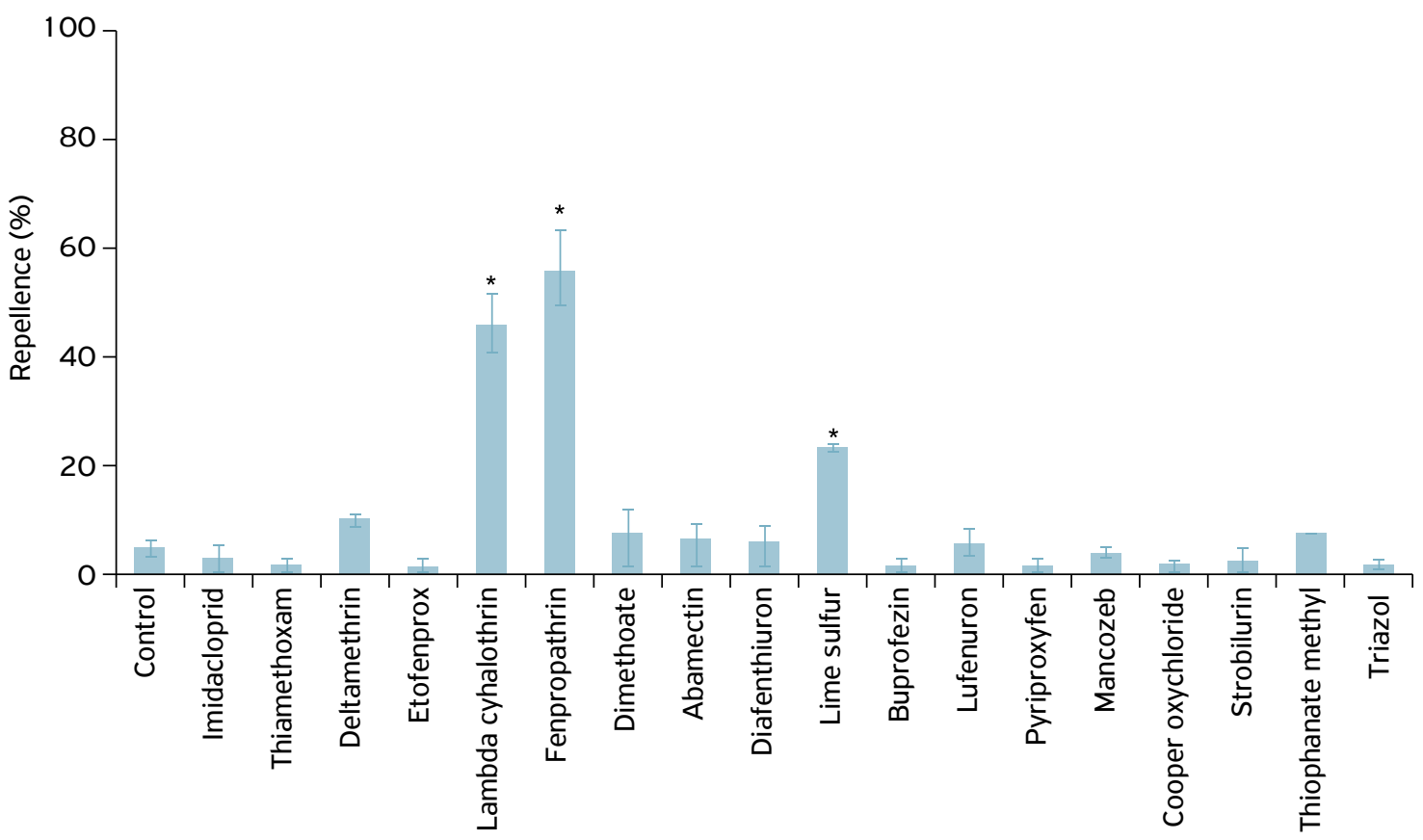

*Significant treatment effect on avoidance adults.

Figure 3. Pesticide effect on repellence (\%) to Panonychus citri. 
these products. Among the sublethal effects, avoidance and hormoligosis can be key factors in pest resurgence (JONES; PARRELLA, 1984; GRAFTON-CARDWELL et al., 2008).

This study tried to present a perspective for suitably positioning products used in citrus pest and disease control for different periods of $P$. citri occurrence. The population density of $P$. citri throughout the year shows negative correlations with temperature and rainfall variables. Warmer and wetter periods would be unfavorable for mite pests, with the largest population peak observed

Treated Untreated

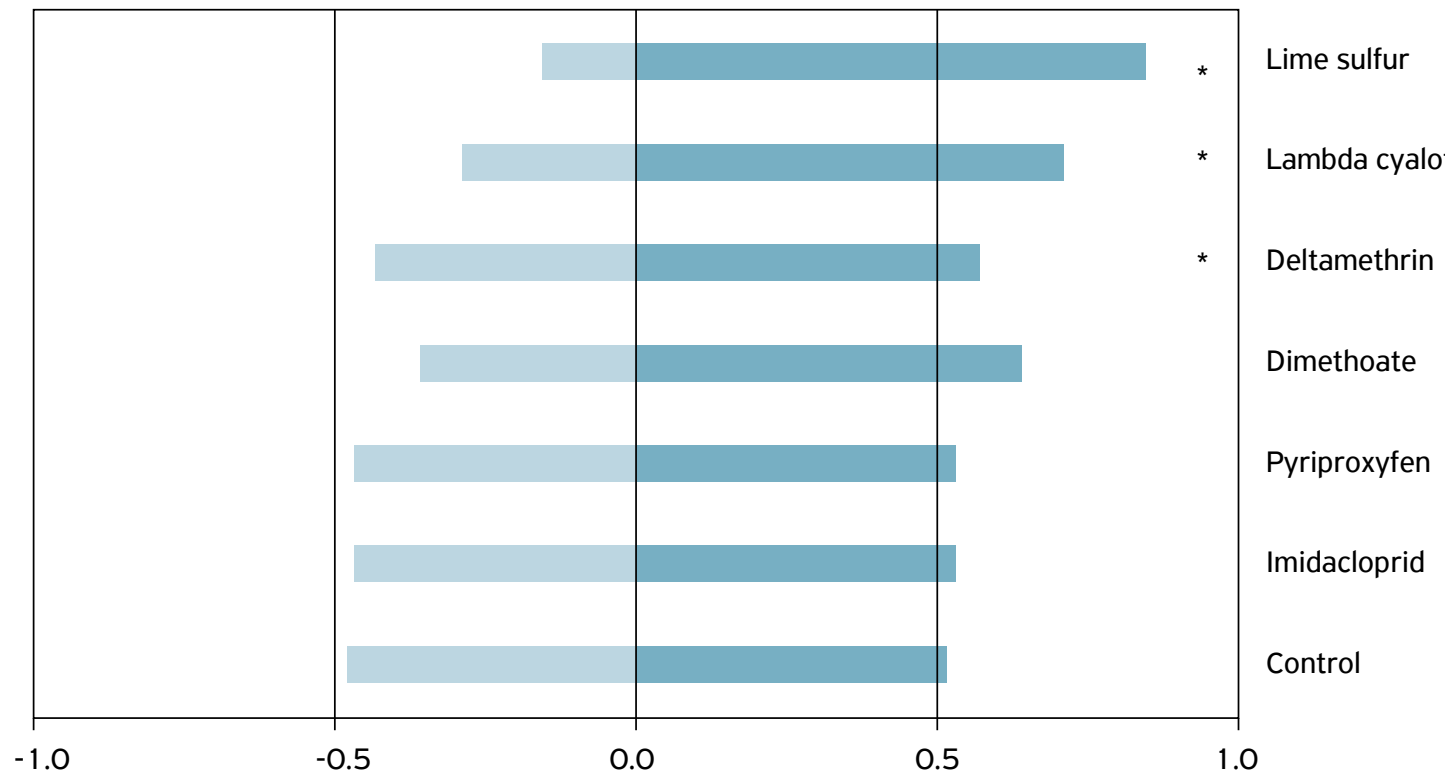

*Significant effect on oviposition behavior.

Figure 4. Oviposition behavior of Panonychus citri on discontinuous pesticide residues, $48 \mathrm{~h}$ after infestation.

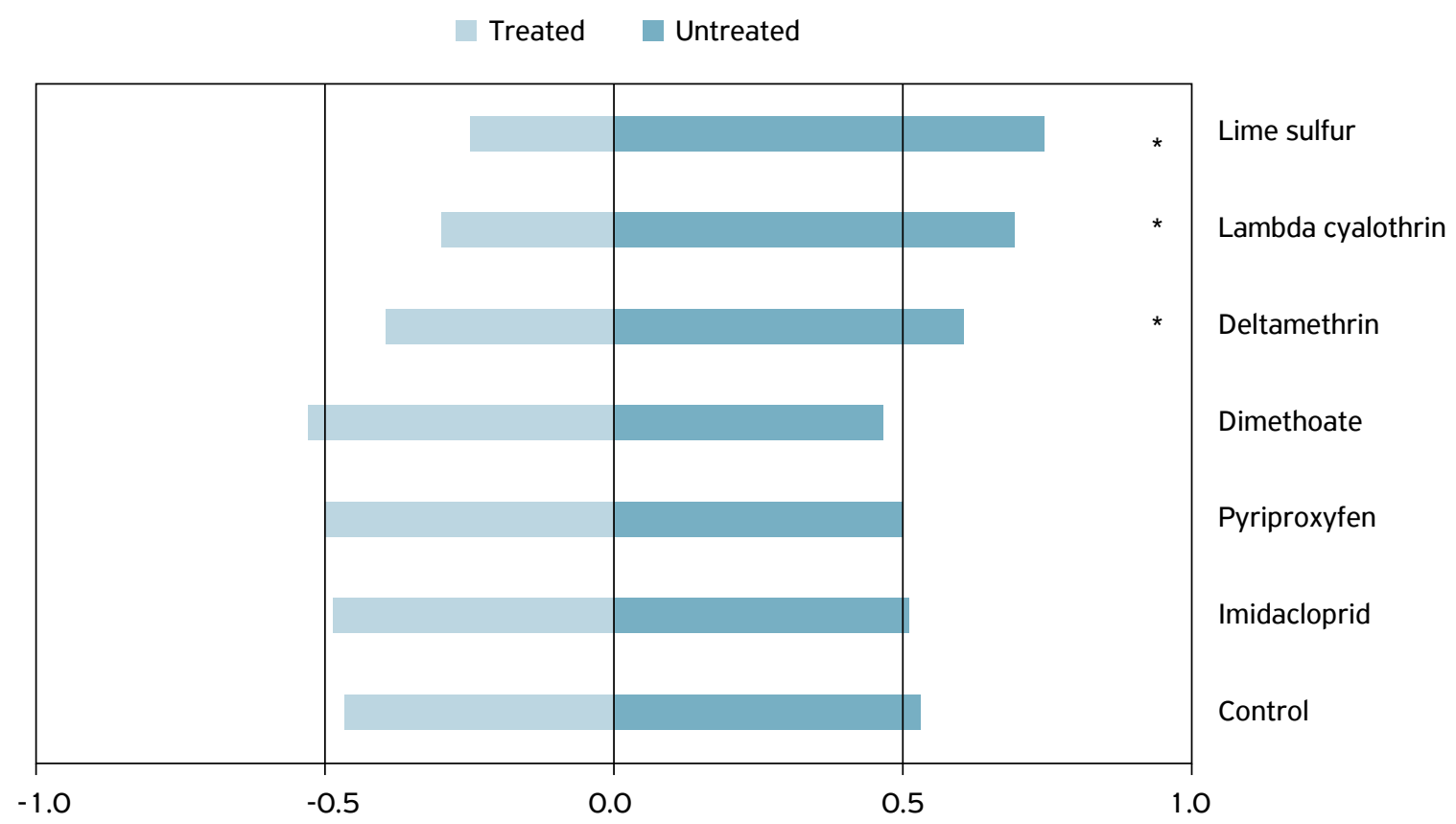

*Significant effect on preference for untreated areas.

Figure 5. Preference of adult Panonychus citri females for insecticide treated and untreated areas. 
between June and July - the driest and cold months (SILVA et al., 2012).

Considering the products evaluated, abamectin, dimethoate and diafenthiuron should be recommended for pest management in citrus in the periods from April to September, when population density of $P$. citri increases, because they act on the adult stage and/or egg viability of this mite. In addition, they can help control and delay the need for using specific acaricides for managing Brevipalpus yothersi resistance (OMOTO et al., 2008). Another fact, which suggests that these products should be recommended when P. citri is present, is the absence of repellent effects on this pest, which could aggravate the problem of this mite dispersing to other citrus plants and areas. Deltamethrin, fenpropathrin, lambda-cyhalothrin and lime sulfur should be avoided during the dry periods. These pesticides should be recommended during rainy periods (October to March), when P. citri infestations are low.

Other evaluated products, such as neonicotinoid insecticides, growth regulators and fungicides, did not have effect neither on adult mortality nor on egg viability in $P$. citri. Moreover, these products do not cause avoidance in $P$. citri and may not favor the increase of $P$. citri population in citrus groves.

\section{ACKNOWLEDGMENTS}

We thank Fundo de Defesa da Citricultura (FUNDECITRUS), for granting a research fellowship.

\section{REFERENCES}

BEARD, J.; OCHOA, R.; BRASWELL, W.E.; BAUCHAN, G.R. Brevipalpus phoenicis (Geijskes) species complex (Acari: Tenuipalpidae) - a closer look. Zootaxa, v.3944, n.1, p.1-67, 2015. http://dx.doi. org/10.11646/zootaxa.3944.1.1

BOBOT, T.E.; FRANKLIN, E.; NAVIA, D.; GASNIER, R.J.; LOFEGO, A.C.; OLIVEIRA, B.M. Mites (Arachnida, Acari) on Citrus sinensis L. Osbeck orange trees in the State of Amazonas, Northern Brazil. Acta Amazonica, v.41, n.4, p.557-566, 2011. http://dx.doi. org/10.1590/SO044-59672011000400013

BOWIE, M.H.; WORNER, S.P.; KRIPS, O.E.; PENMAN, D.R. Sublethal effects of esfenvalerate residues on pyrethroid resistant Typhlodromus pyri (Acari: Phytoseiidae) and its prey Panonychus ulmi and Tetranychus urticae (Acari: Tetranychidae). Experimental and Applied Acarology, v.25, p.311-319, 2001.

COSTA, M.G.; BARBOSA, J.C.; YAMAMOTO, P.T.; LEAL, R.M. Spatial distribution of Diaphorina citri Kuwayama (Hemiptera: Psyllidae) in citrus orchards. Scientia Agricola, v.67, n.5, p.546-554, 2010.

FADOMIRO, H.Y.; AKOTSEN-MENSAH, C.; XIAO, Y.; ANIKWE J. Field evaluation of predacious mites (Acari: Phytoseiidae) for biological control of citrus red mite, Panonychus citri (Trombidiformes: Tetranychidae). Florida Entomologist, v.96, n. 1, p.80-91, 2013.

GRAFTON-CARDWELL, E.E.; LEE, J.E.; ROBILLARD, S.M.; GORDEN, J.M. Role of imidacloprid in integrated pest management of California citrus. Journal of Economic Entomology, v.101, n.2, p.451-460, 2008.

HE, H.G.; JIANG, H.B.; ZHAO, Z.M.; WANG, J.J. Effects of a sublethal concentration of avermectin on the development and reproduction of citrus red mite, Panonychus citri (McGregor) (Acari: Tetranychidae). International Journal of acarology, v.37, n.1, p.1-9, 2011 . http://dx.doi.org/10.11158/ saa.19.4.11
HU, J.; WANG, C.; WANG J.; YOU, Y; CHEN, F. Monitoring of resistance to spirodiclofen and five other acaricides in Panonychus citri collected from Chinese citrus orchards. Pest Management Science, v.66, p. 1025-1030, 2010. http://dx.doi. org/10.1002/ps.1978

JONES, V.P.; PARRELLA, M.P. The sublethal effects of selected insecticides on life table parameters of Panonychus citri (Acari: Tetranychidae). The Canadian Entomologist, v.116, p.1033-1040, 1984.

KASAP, I. The biology and fecundity of the citrus red mite Panonychus citri (McGregor) (Acari: Tetranychidae) at different temperatures under laboratory conditions. Turkish Journal of Agriculture and Forestry, v.33, p.593-600, 2009. http://dx.doi. org/10.3906/tar-0902-41

KOLMES, S.A.; DENNHY, T.J.; BROADWATER, E. Effects of residence time and webbing upon dicofol-avoidance behavior in two-spotted spider mites (Acari: Tetranychidae). Experimental and Applied Acarology, v.12, n.3, p.181-193, 1991.

MINEIRO, J.L.; SATO, M.E.; NOVELLI, V.M.; ANDRADE, D.J. Distribuição de Brevipalpus yothersi Baker, 1949 (Acari: Tenuipalpidae) em diferentes hospedeiras e localidades no estado de São Paulo. Biológico, São Paulo, v.77, n.2, p.73-111, 2015.

NOHARA, K.; NAKAO, S.; NAGATOMI, A. A study of the relationship between pesticide treatment and the fauna in citrus groves on Nagashima Island, Kagoshima prefecture. Applied Entomology and Zoology, v.35, n.2, p.271-281, 2000.

OMOTO, C.; ALVES, E.B.; CAMPOS. F.J.; FRANCO. C.R.; CASARIN. N.F.B.; POLETTI. M.; KONNO. R.H. Resistência de Brevipalpus phoenicis em pomares de citros do Estado de São Paulo, In: Manejo Integrado de Pragas dos citros, ed. by Yamamoto, P.T., Fundecitrus, Piracicaba, v. 1, p127-154, 2008. 
QURESHI, J.A.; KOSTYK, B.C.; STANSLY, P.A. Insecticidal suppression of Asian Citrus Psyllid Diaphorina citri (Hemiptera: Liviidae) vector of Huanglongbing pathogens. PLOS ONE, http:// dx.doi.org/10.1371/journal.pone.0112331, 2014.

ROBERTO, S.R.; BORGES, A.V. Flower bud stage and fungicide application effect control on postbloom fruit drop of citrus. Revista Brasileira de Fruticultura, v.23, n.2, p.306-309, 2009.

ROSSETTO, M.P.; AZEVEDO, F.A.; MARTELLI, I.B.; CHINOR, E.H. Evolution of citrus black spot in different varieties of sweet orange. Bragantia, v.70, n. 1, p.58-63, 2011.

SAS INSTITUTE. Statistical Analysis System: Getting Started with the SAS Learning. SAS Institute, Cary, NC, 2002.

SATO, M.E.. Perspectives of the use of predaceous mites for the biological control of phytophagous mites on citrus. Laranja, v.26, n.2, p.291-306, 2005

SATO, Y.; MORYAMA, S.; UCHIYAMA, T.; SEKI, M. Effect of a mixture of acephate and fenpropathrin on the citrus red mite, Panonychus citri (McGregor). Japanese Journal Applied Entomology and Zoology, v.36, p.17-23, 1992.

SILVA, M.Z.; SATO, M.E.; OLIVEIRA, C.A.L. Diversity and population dynamics of mites in citrus orchard. Bragantia, v.71, n.2, p.210-218, 2012.http://dx.doi.org/10.1590/SO006-87052012005000013
TEODORO, A.V.; PALLINI, A.; OLIVEIRA, C. Sub-lethal effects of fenbutatin oxide on prey location by the predatory mite Iphiseiodes zuluagai (Acari: Phytoseiidae). Experimental and Applied Acarology, v.47, p.293-299, 2009. http://dx.doi.org/10.1007/ s10493-008-9219-x

YAMAMOTO, P.T.; FELIPPE, M.R.; SANCHES A.L.; COELHO, J.H.C.; GARBIM, L.F.; XIMENES, N.L. Efficacy of insecticides for managing Diaphorina citri Kuwayama (Hemiptera: Psyllidae) in citrus. BioAssay, v.4, n.4, 2009. http://dx.doi.org/10.14295/ BA.v4.0.21

YAMAMOTO, P.T.; ZANARDI, O.Z. Atualização de manejo do ácaro purpúreo Panonychus citri. Revista Citricultura Atual, Cordeirópolis, v.96, p. 16-17, 2013.

ZANARDI, O.Z.; BORDINI, G.P.; FRANCO, A.A.; MORAIS, M.R.; YAMAMOTO, P.T. Development and reproduction of Panonychus citri (Prostigmata: Tetranychidae) on different species and varieties of citrus plants. Experimental and Applied Acarology, v.67, n.4, p.1-17, 2015. http://dx.doi.org/10.1007/ s10493-015-9968-2

ZANARDI, O.Z. Mecanismos associados à ocorrência de surtos populacionais e manejo de Panonychus citri (McGregor) (Acari: Tetranychidae) em pomares cítricos. Piracicaba, 2015. 134p. Tese (Doutorado) - Escola Superior de Agricultura "Luiz de Queiroz", Universidade de São Paulo, Piracicaba, 2015. 